Anthropos: Jurnal Antropologi Sosial dan Budaya 4 (2) (2019): 152-160.

DOI: https://doi.org/10.24114/antro.v4i2.11957

\title{
ANTHROPOS:
}

Jurnal Antropologi Sosial dan Budaya

Available online http://jurnal.unimed.ac.id/2012/index.php/anthropos

\section{Ideologi Gender pada Perempuan Pakpak}

\author{
Hadriana Marhaeni Munthe* \\ Departemen Sosiologi, Fakultas Ilmu Sosial dan Ilmu Politik \\ Universita Sumatera Utara, Indonesia \\ Diterima: Januari; Disetujui: Januari; Diterbitkan: Januari
}

\begin{abstract}
Abstrak
Studi ini bertujuan mengkaji tentang konstruksi ideologi gender perempuan melalui kasus-kasus marginalisasi perempuan dalam keluarga masyarakat Pakpak di desa Pegagan Julu VIII Kabupaten Dairi, Sumatera Utara. Metode pendekatan yang digunakan adalah kualitatif dengan desain penelitian studi kasus berperspektif feminis. Melalui metode studi kasus, data yang ada dikembangkan dengan berbagai macam fakta ke kasus tunggal, sehingga data terkait dimanfaatkan secara maksimal untuk mencapai analisis yang dalam dan lengkap. Teknik pengumpulan data menggunakaan FGD (Focus Group Discussion), wawancara mendalam dan observasi partisipan pada perempuan yang menjadi informan penelitian. Teknik pengumpulan data menggunakaan FGD (Focus Group Discussion), wawancara mendalam dan observasi partisipan pada perempuan yang menjadi informan penelitian.Hasil studi memperlihatkan bahwa konstruksi ideologi gender perempuan Pakpak di keluarga adalah ideologi gender patriarkis yang terlekat pada nilai-nilai peribuan perempuan Pakpak.
\end{abstract}

Kata Kunci: Ideologi Gender, Perempuan Pakpak

\begin{abstract}
This study aims to examine the construction of women's gender ideology through cases of marginalization of women in the Pakpak community in Pegagan Julu VIII, Dairi District, North Sumatra. The approach method used is qualitative with a feminist perspective case study design. Through the case study method, the existing data is developed with a variety of facts into a single case, so that the related data is fully utilized to achieve a deep and complete analysis. Data collection techniques used FGD (Focus Group Discussion), in-depth interviews and participant observation on women who became research informants. Data collection techniques used FGD (Focus Group Discussion), in-depth interviews and participant observation on women who became research informants. The results of the study showed that the construction of Pakpak women's gender ideology in the family was a patriarchal gender ideology that was attached to Pakpak women's values.
\end{abstract}

Keywords: Gender ideology, Pakpak women

How to Cite: Munthe, H.M (2019). Ideologi Gender pada Perempuan Pakpak. Anthropos: Jurnal Antropologi Sosial dan Budaya, 4 (2): 152-160.

Penelitian didanai Talenta USU, Nomor: 2590/UN5.1.R/PPM/2018 tanggal 16 Maret 2018.

\begin{tabular}{lr}
\hline *Corresponding author: & ISSN 2460-4585 (Print) \\
E-mail: hadrianamunthe@yahoo.com & ISSN 2460-4593 (Online)
\end{tabular}




\section{PENDAHULUAN}

Beberapa studi mengkaji budaya patriarki menjadi penyebab terjadinya marginalisasi, kekerasan maupun pensubordinasian perempuan di masyarakat etnis Pakpak (Padang, 2009, Pardede, 2010, Bangun, 2013, Tinendung, 2011). Lebih jauh lagi studi-studi ini merekomendasikan solusi kultural untuk menyelesaikan persoalan ketimpangan gender pada perempuan. Memang tidak bisa dipungkiri bahwa studi-studi tersebut mampu menjelaskan ketimpangan perempuan Pakpak bermuara dari patriarki yang didudukkan dalam kerangka analisis budaya. Namun sejauh ini studi yang ada tidak mengkaji keberadaan aktor sosial sebagai pelaku patriaki yang menguatkan struktur ketimpangan gender di tengah masyarakat Pakpak. Akibatnya solusi-solusi mengatasi ketimpangan gender pada perempuan Pakpak sebagaimana yang diusulkan oleh studi terdahulu sampai sejauh ini belum sepenuhnya bisa menjawab persoalan yang dihadapi perempuan Pakpak terutama bagi mereka yang berada di pedesaan.

Selain studi ketimpangan gender yang bermuara pada feneomena kultural maka studi lain menemukan bahwa faktor keaktoran sosial juga dominan membentuk gejala ketimpangan gender pada perempuan di pedesaan (Munthe, 2017). Studi ini menemukan kasus-kasus marginalisasi terjadi pada perempuan di keluarga miskin bahkan juga keluarga yang berekonomi relatif baik.Studi tersebut melihat bahwa keluarga miskin cenderung melakukan praktik diskriminasi dan marginalisasi pada anak perempuan mengakses pendidikan jenjang Sekolah Menengah Pertama dan Atas. Sementara marginalisasi pendidikan terjadi pada anak perempuan pendidikan tinggi (Universitas) di keluarga yang relatif kaya.

Merujuk pada studi Munthe mengindikasikan bahwa keluarga sebagairepresentasi struktur sosial sangat potensial mempertahankan nilai dan norma patriarki.Lebih jauh lagi studi ini menegaskan bahwadalam insitusi sosial seperti keluarga ditemukan kasus-kasus marginalisasi perempuan yang erat dengan keberadaan orangtua, saudara laki-laki maupun ipar sebagai pelaku atau aktor sosial yang berpotensi menindas perempuan.Studi ini juga relevan dengan studi lain yang menempatkan keberadaan laki-laki sebagai aktor sosialatau pelaku utama yang mengkonstruksi, memproduksi dan mereproduksi nilai-nilai patriarki
(Chester dkk,1944 ; Narayan, 1997; Cravey, 1998; Shirkat, 2001; McFadden, 2001; Alpizar, 2003; Maria, 2003; Cevallos, 2003; Hunter, 2005; Pantaleo, 2006 ; Erturk, 2007; Panther, 2007; Martinez, 2008; Menjivar, 2008; Agarwal, 2009; Abell, 2009; Naeem, 2011). Sementara realitas maupun fakta yang mengungkapkan perempuan sebagai aktor reproduksi patriarki sejauh ini belum banyak dikaji atau diungkapkan dalam penelitian. Ada beberapa kajian tentang keaktoran sosial yang memperlihatkan keberadaan perempuan sebagai aktor reproduksi dan resistensi budaya (Tridewiyanti, 2009) pada masyarakat Arab di Jakarta. Berikutnya studi yang mengungkapkan keberadaaan perempuan sebagi agen sosialisasi di keluarga yang berbudaya patrilineal dilakukan dalam konteks masyarakat Batak Pakpak di pedesaan (Pardede, 2010; Tinendung, 2011 dan, Munthe, 2017).

Dari studi-studi isu gender tentang fenomena ketimpangan perempuan di masyarakat Pakpak sampai sejauh ini belum mengkaji seperti apakah konstruksi ideologi gender perempuan sebagai aktor atau agen sosialisasi keluarga yang terkait pula dengan latarbelakang kompleksitas isu-isu gender di masyarakat Pakpak yang memiliki latarbelakang keragaman suak. Berdasarkan literature masyarakat Pakpak diketahui bahwa wilayah persebaran masyarakat Batak Pakpak atau diistilahkan dengan Tanoh Pakpak (Berutu, 1998) dapat diklasifikasikan menjadi lima bagian besar yang disebut Suak, yaitu: 1, Pakpak Simsim, yakni orang Batak Pakpak yang menetap dan memiliki hak ulayat di wilayah Simsim meliputi wilayah Salak, Situje, Situju, Kerajaan, Pergetteng-getteng Sengkut, Tinada dan Jambu. Marga-marganya antara lain Berutu, Padang, Solin, Cibro, Sinamo, Boang Manalu, Manik, Banurea, Sitakar, Kabeaken, Lembeng, Tinendung dan lain-lain. 2, Pakpak Keppas, yakni orang Batak Pakpak yang menetap dan memiliki hak ulayat di wilayah Sidikalang, Siteelu Nempu, Siempat Nempu, Silima PunggaPungga, Tanoh Pinem, Parbuluan, Lae Hulung. Adapun marga-marganya yaitu Angkat, Bintang, Capah, Ujung, Berampu, Pasi, Maha, dan lain-lain. 3, Pakpak Pegagan, yakni orang Batak Pakpak yang menetap dan memiliki hak ulayat di wilayah Pegagan meliputi Sumbul, Tiga Baru, Silalahi, dan Tiga Lingga. Adapun marga-marganya Berdasarkan literature masyarakat Pakpak diketahui bahwa wilayah persebaran masyarakat Batak Pakpak atau diistilahkan 
dengan Tanoh Pakpak (Berutu, 1998) dapat diklasifikasikan menjadi lima bagian besar yang disebut Suak, yaitu: 1, Pakpak Simsim, yakni orang Batak Pakpak yang menetap dan memiliki hak ulayat di wilayah Simsim meliputi wilayah Salak, Situje, Situju, Kerajaan, Pergetteng-getteng Sengkut, Tinada dan Jambu. Margamarganya antara lain Berutu, Padang, Solin, Cibro, Sinamo, Boang Manalu, Manik, Banurea, Sitakar, Kabeaken, Lembeng, Tinendung dan lain-lain. 2, Pakpak Keppas, yakni orang Batak Pakpak yang menetap dan memiliki hak ulayat di wilayah Sidikalang, Siteelu Nempu, Siempat Nempu, Silima Pungga-Pungga, Tanoh Pinem, Parbuluan, Lae Hulung. Adapun marga-marganya yaitu Angkat, Bintang, Capah, Ujung, Berampu, Pasi, Maha, dan lain-lain. 3, Pakpak Pegagan, yakni orang Batak Pakpak yang menetap dan memiliki hak ulayat di wilayah Pegagan meliputi Sumbul, Tiga Baru, Silalahi, dan Tiga Lingga. Adapun marga-marganya yaitu Lingga, Matanari, Maibang, Kaloko, Manik Sikettang, dan lainlain. 4. Pakpak Kelasen, yakni orang Batak Pakpak yang menetap dan memiliki hak ulayat di wilayah Kelasen meliputi wilayah Parlilitan, Pakkat, Barus dan Manduamas. Mereka umumnya bermarga Tinambunan, Tumangger, Turuten, Maharaja, Pinayungen, Anak Ampun, Berasa, Gajah, Ceun, Meka, Mungkur, Kesogihen dan lain-lain. 5, Pakpak Boang, yakni orang Batak Pakpak yang menetap dan memiliki hak ulayat di wilayah Boang meliputi Aceh Singkil yakni Simpang Kiri, Simpang Kanan, Lipat Kajang dan Kota Subulussalam. Adapun marga Saraan, Sambo, Bancin, Kombih, Penarik, dan lain-lain.

Ketimpangan gender cenderung dialami oleh perempuan dalam masyarakat Pakpak yang memiliki sistem kekerabatan patrilineal dan berlatarbelakang suak. Gambaran ketimpangan gender dinyatakan dalam bentuk marginalisasi subordinasi kekerasan maupun diskriminasi. Fenomena ketimpangan gender juga dialami oleh perempuan Pakpak desa Pegagan Julu mewakili suak Pagagan. Ketimpangan gender yang dialami perempuan desa Pegagan Julu VIII dikaitkan dengan konstruksi ideologi gender perempuan sebagai aktor atau agen sosialisasi keluarga yang berpotensi melanggengkkan struktur patriarki. Studi ini mengkaji bagaimanakah konstruksi ideologi gender perempuan Pakpak yang dikemukakan dari kasus-kasus marginalisasi perempuan di keluarga masyarakat etnis Pakpak desa Pegagan Julu VIII.

\section{METODE PENELITIAN}

Penelitian ini menggunakan pendekatan kualitatif dengan desain penelitian studi kasus yang berperspektif feminis. Studi kasus feminis biasanya menekankan pada deskripsi yang dalam dan lengkap mengenai studi peristiwa orang, kelompok, organisasi atau komunitas tunggal. Peneliti feminis menyatakan bahwa teori feminis akan termiskinkan tanpa studi kasus. Hal ini mengandung pengertian bahwa untuk memahami perempuan perlu dilakukan kajian secara mendalam terhadap kasus-kasus yang dialaminya. Penentuan studi kasus dalam penelitian feminis didorong oleh keinginan untuk meluruskan penelitian yang dinodai oleh gynopia, misogini, dan penyusunan teori yang didominasi oleh laki-laki. Melalui metode studi kasus, data yang ada dikembangkan dengan berbagai macam fakta yang lain ke kasus tunggal sehingga data terkait dimanfaatkan secara maksimal untuk mencapai analisis yang dalam dan lengkap. Di dalam pendekatan ini bersandar pada asumsi bahwa kasus yang diteliti bersifat khas untuk kasus jenisjenis tertentu sehingga melalui analisa mendalam, bisa dibuat generalisasi yang akan bisa diterapkan untuk kasus-kasus lain dari jenis yang serupa (Maquaire, 1986; Reinhartz,1992; Wolf, 1996; Ramazanoglu and Holland, 2002; Venny, 2006; Pardede, 2010) .

Sesuai dengan design penelitian yaitu studi kasus, maka penelitian ini mengemukakan kasuskasus marginalisasi perempuan yang diperoleh dari berbagai sumber. Informasi kasus bersumber dari masyarakat setempat, biro pemberdayaan perempuan pemerintahan desa. Informasi tentang kasus marginalisasi juga didapatkan langsung dari perempuan serta tokoh masyarakat. Selain informasi dari sumber tersebut, data pendukung lainnya juga diperlihatkan oleh data ketimpangan tingkat pendidikan penduduk berdasarkan jenis kelamin desa Pegagan Julu VIII. Demikian juga hasil observasi data lapangan yang dilakukan pada Maret sampai Mei 2014 menunjukkan bahwa dari 150 kepala keluarga Pakpak berkecenderungan melakukan praktik-praktik marginalisasi pendidikan serta hak pewarisan terhadap anak perempuan di keluarga.

Sekitar bulan September dan Oktober 2014 didapatkan sekitar 50 kasus marginalisasi perempuan di keluarga yang memperlihatkan potensi perempuan sebagai aktor reproduksi patriarki. Setelah mempelajari dan mendidkusikan kasus dengan team peneliti bulan Desember 2014, 
akhirnya difokuskan studi pada sepuluh kasus marginalisasi perempuan. Demikian juga setelah melakukan pendekatan yang intens akhirnya tercapai trust dan rappot antara peneliti dan perempuan yang mengalami praktik marginalisasi dengan kesediaan mereka menjadi informan. Masing-masing tiga kasus marginalisasi pendidikan pada anak perempuan keluarga yang dikepalai oleh perempuan janda (miskin) dan lima kasus marginalisasi pendidikan dan warisan pada perempuan keluarga miskin dan dua kasus marginalisasi pendidikan perempuan pada keluarga kaya.

Penentuan perempuan yang bersedia menjadi informan didasarkan pada karakteristik sosial yaitu usia, status perkawinan, klen (berru) (yaitu Istilah klen dalam kekerabatan masyarakat Pakpak patrilineal, pada laki-laki disebut merga dan pada perempuan disebut berru),pendidikan, pekerjaan, dan tempat tinggal (sesuai dengan karakteristik keluarga Pakpak).

\section{HASIL DAN PEMBAHASAN}

\section{Ideologi Gender Masyarakat Pakpak}

Konsep gender dimaknai sebagai suatu perbedaan yang bukan biologis dan bukan kodrat (Oakley, 1972; Moser, 1993; William dkk, 1994; Wijaya 1996). Caplan (dalam Abdullah, 2001) menguraikan bahwa perbedaan perilaku antara laki-laki dan perempuan tidaklah sekedar biologi, namun melalui proses sosial dan kultural. Oleh karena itu gender terikat oleh budaya, ruang dan waktu, berubah dari waktu ke waktu dan tempat ke tempat bahkan dari kelas ke kelas, sedangkan jenis kelamin biologis (sex) akan tetap tidak berubah.

Seringkali gender menjadi sumber polemik dalam masyarakat yang cenderung merugikan kelompok tertentu yaitu perempuan. Berbagai realitas gender memperlihatkan bahwa perempuan lebih banyak mengalami berbagai kekerasan fisik dan non-fisik di dalam berbagai masyarakat dan budaya.Kehadiran anak laki-laki lebih dikehendaki daripada anak perempuan.Demikian pula banyak budaya di masyarakat memperlakukan anak lakilaki lebih istimewa daripada anak perempuan. Dalam program pembangunan masyarakat, perempuan kurang dilibatkan atau seringkali kepentingannya diabaikan sehingga atas nama pembangunan pula perempuan sebagai pihak yang seringkali dikorbankan. Akibatnya gejala pemiskinan perempuan maupun feminisasi kemiskinan dan berbagai penderitaan lainnya semakin berat dialami oleh perempuan karena status gendernya. Anggapan ini disuarakan oleh kelompok pemerhati perempuan atau feminis. Dari keseluruhan isu-isu gender yang dikemukakan itu dapat ditarik benang merah bahwa perempuan memang menghadapi suatu persoalan yang terlekat dan melekat dengan identitas, status dan peran gendernya (Budiman, 1981; Andersen, 1983; Fakih,1996, Munthe, 2016, Munthe 2017).

Berkenaan dengan persoalan tentang gender ini maka Fakih (1996) dan Abdullah (2001) dua akademisi laki-laki yang feminis memberikan suatu pandangan dan jawaban kritis. Keduanya menganalisis bahwa konsep gender akan menjadi suatu persoalan ketika perbedaan gender yang telah ada berproses dalam sistem sosial dan budaya berubah jadi suatu ideologi gender yang menciptakan nilai atau pandangan bias pada perempuan. Akibat yang ditimbulkannya di kemudian hari yaitu ketimpangan berupa adanya pandangan, perlakuan maupun berbagai tindakan terhadap kehidupan perempuan yang bersifat tidak adil di dalam masyarakatnya.

Gagasan yang dikemukakan akademisi feminis mengenai konsep gender yang kemudian berproses menjadi ideologi gender dijadikan sebagai acuan menjelaskan tentang ideologi gender pada masyarakat Pakpak. Gagasan ini dipakai karena secara spesifik belum ada studi yang mengkaji konsep gender pada masyarakat Pakpak. Hanya saja beberapa studi menyinggung bagaimana relasi gender dan peranan gender dipraktikkan dalam masyarakat Pakpak melalui studi-studi tentang ketimpangan perempuan Pakpak (Boangmanalu, 2009, Tinendung, 2010, Pardede, 2010, Bangun, 2013, dan Munthe, 2017). Studi inimengisyaratkan terdapatrelasi gender yang timpang pada perempuan apabila ditinjau dalam konteks kehidupan masyarakat desa yang kuat menjalankan nilai-nilai adat. Adat memainkan peran sebagai pengatur kehidupan dan menentukan keberlangsungan hidup masyarakat Pakpak sehingga ketaatan dan kepatuhan pada nilai-nilai adat sangat diutamakan di dalam komunitas ini. Namun dalam konteks adat, perempuan seringkali ditempatkan pada posisi yang marginal dan tersubordinasi oleh kaum lakilaki sebab sistem pembagian kerja dalam kegiatan- 
kegiatan yang umum dilakukan dalam adat Pakpak didominasi oleh laki-laki.Hal ini terlihat dalam sistem pembagian kerja seksual dalam adat menempatkan laki-laki sebagai pembicara, perencana dan pengatur kegiatan di adat.Sebaliknya perempuan dilarang berbicara sebab tidak dibenarkan oleh aturan adat.Mereka biasanya hanya diposisikan sebagai pendengar dan menerima segala putusan adat untuk dilaksanakan.Intinya perempuan diposisikan sebagai pekerja adat bukan sebagai konseptor atau pemimpin adat.

Masyarakat Pakpak di pedesaan sangat setia pada nilai-nilai tradisional dan mereka mensakralkan nilai adatnya sebagaimana halnya pada masyarakat Batak Toba, Karo, Simalungun maupun Mandailing yang juga berlatarbelakang sistem kekerabatan patrilineal. Pada masyarakat patrilineal sangat kuat mengkonstruksi budaya patriarki yang sarat dengan kekuasaan patriarki. Pengaruh kekuasaan patriarki terlihat di berbagai elemen struktur sosial yang sangat dekat yaitu lembaga keluarga. Bahkan kekuasaan patriarki tertanam dalam lembaga lainnya yaitu lembaga hukum, adat, politik bahkan agama (Ihromi, 1986, Simbolon, 1998, Irianto, 2003, Simanjuntak, 2006).

Intinya studi-studi ketimpangan perempuan Pakpak memberikan isyarat bahwa pintu masuk memahami ideologi gender diletakkan dalam kerangka sistem kekerabatan masyarakat Pakpak yang patrilineal.Lebih jelasnya perwujudan dari sistem kekerabatan patrilineal Pakpak dinyatakan dalamadat sebagai kumpulan nilai-nilai yang melembaga dan dianggap sangat sakral. Dalam adat terdapat norma yang mengatur peran sekaligus hubungan laki-laki dan perempuan yang kemudian dijadikan landasan bagi lembaga-lembaga sosial yang adadi masyarakat Pakpak termasuk keluarga. Nilai-nilai adat dijadikan referensi norma yang mengatur laki-laki dan perempuan di dalam keluarga bahkan lembaga lain yang ada di masyarakat Pakpak.

Keberadaan adat sebagai norma sentral penjaga keteraturan dan keharmonisan dalam masyarakat Pakpak sebenarnya berakar pada nilainilai patriarkhi yang sangat sarat denganberbagai praktik ketidakadilan pada perempuan. Adat sebagai representasi sistem kekerabatan patrilineal ternyata mengkonstruksi hubungan hierarkhis yang menempatkan laki-laki sebagai posisi superior dan perempuan pada posisi tersubordinat (Bangun, 2009, Pardede, 2010, Munthe, 2017). Dalam konteks adat, norma patriarki menempatkan laki-laki sebagai raja atau pemimpin. Laki-laki yang berwenang memimpin setiap kegiatan adat sehingga posisi sosial laki-laki sangat istimewa dan dihargai. Sebaliknya perempuan hanya sebatas pelaksana dan pihak yang mengerjakan putusan adat. Perempuan tidak diperkenankan berbicara dan berwenang memimpin adat sehingga berkonsekuensi pada posisi yang lemah dan cenderung tersubordinasikan oleh adat.Realitas posisi perempuan yang tersubordinasi dalam adat merefleksikan relasi gender yang berimbas pula pada konstruki relasi gender di lembaga keluarga, perkawinan dan pewarisan. Ketentuan adat memberlakukan sistem pewarisan yang menempatkan laki-laki sebagai ahli waris utama terutama harta pusaka. Dalam setiap kegiatan adat memberikan posisi laki-laki sebagai pemeran utama dan laki-laki dianggap sebagai wakil keluarga dalam adat.

Selain meggunakan kerangka sistem kekerabatan yang patrilineal untuk menjelaskan relasi gender maka petunjuk lainnya menjelaskan peran gender pada masyarakat Pakpak dapat dilihat dari sistem pembagian kerja seksual yang berlangsung di masyarakat Pakpak (Bangun, 2009; Munthe, 2017).Berdasarkan studi Munthe (2017) menegaskan bahwa sistem pembagian kerja yang berlaku di keluarga Batak Pakpak terutama keluarga miskin menempatkan perempuan tidak hanya pada peran domestik melainkan pemeran utama menopang ekonomi rumahtangga di sektor publik (aktivitas berladang, berkebun dan berternak) bahkan mereka dituntut berpartisipasi dalam kegiatan adat. Sementara pekerjaan laki-laki lebih terkonsentrasi pada peran di luar rumah atau peran publik seperti mengurus ladang, ternak, kebun dan peran dalam adat.

Dalam konteks pembagian kerja seksual yang menempatkan perempuan pada berbagai tugas dan tanggungjawab domestik maupun publik seringkali tidak berbanding lurus dengan peran laki-laki. Artinya, tatkala perempuan sudah terlibat melakukan peran produktif ternyata sebaliknya laki-laki masih enggan terlibat dalam pekerjaan domestik sehingga proses domestifikasi tidak terjadi pada peran gender laki-laki. 
Studi Munthe (2017) menegaskan bahwa sistem pembagian kerja seksual dalam masyarakat Pakpak sangat patriarkis sebagai konstruksi ideologi gender patriarkis yang cenderung dipraktekkan terutama pada keluarga miskin di pedesaan. Ideologi gender yang patriarkis ini semakin subur ketika kemiskinan membingkai kehidupan keluarga sehingga sangat rentan menimbulkan bias pada laki-laki dan mengindikasikan terjadinya praktik-praktik ketimpangan genderterhadap perempuan. Sistem pembagian kerja seksual menghadirkan realitas ketimpangan gender yang dialami oleh perempuan sebagaimana yang tercermin dari kasus-kasus yang dialami oleh anak perempuan yang putus sekolah, perempuan yang tidak memperoleh akses pada warisan. Dalam kasus-kasus tersebut memperlihatkan perempuan memperoleh porsi atau beban kerja yang lebih berat dan sistem ini juga berpotensi memunculkan praktik-praktik ketidakadilan gender. Konkritnya, anak perempuan lebih dikonsentrasikan bekerja membantu orangtua di rumah maupun di ladang sementara anak laki-laki lebih didorong untuk bersekolah. Demikian pula demi alasan kelangsungan pendidikan pada anak laki-laki menyebabkan adanya pembenaran dan legalitas pada mereka untuk mengakses harta warisan ketimbang anak perempuan.

\section{Ideologi Gender Patriarki Perempuan Pakpak}

Ideologi gender patriarki yang sudah berlangsung sedemikian lama dalam masyarakat Pakpakmerupakan warisan budaya yang sangat bernilai luhur tinggi yang sangat disakralkan segenap anggota masyarakat Pakpak. Ideologi gender patriarki yang sedemikian pada akhirnya dipandang sebagai kearifan lokal yang dipertahankan nilai-nilainya hingga ke generasi yang ada saat ini. Namun harus diakui bahwa realitas ideologi gender ini cenderung lebih kuat dipraktikkan oleh masyarakat Pakpak di perdesaan ketimbang di perkotaan. Hal ini dimungkinkan karena masyarakat Pakpak di perkotaan sudah memodernisasi nilai-nilai gender di keluarganya seperti dalam sistem pewarisan yang sudah diberikan pada perempuan Malau (2013).

Ideologi gender patriarki merupakan sistem yang membudaya dan menstruktur sebagai acuan nilai-nilai moral yang dianggap ideal dan harus dipatuhi oleh laki-laki dan juga perempuan di masyarakatnya.Setidaknya ini terlihat dalam kasuskasus marginalisasi anak perempuan di keluarga miskin yang tidak mendapat akses melanjutkan sekolah ke jenjang sekolah menengah dan lanjutan.Hal yang serupa juga terjadi pada anak perempuan yang dibatasi mengakses pendidikan tinggi (universitas) pada keluarga relatif kaya.Sementara beberapa perempuan mengalami marginalisasi mengakses warisan dari keluarga inti asalnya.

Kasus-kasus ketimpangan gender pada perempuan dalam keluarga Pakpak memiliki keterlekatan dengan peran yang dilakukan oleh aktor-aktor sosial di keluargan. Seringkali peran pengambilan keputusan ditentukan oleh kepala keluarga. Dalam konteks masyarakat Pakpak yang berideologi patriarki menempatkan legalitas lakilaki sebagai kepala atau pemimpin di keluarganya. Legalitas laki-laki sebagai kepala keluarga seringkali terlekat dan terkait dengan legalitas lakilaki sebagai penentu keturunan, penentu marga dan pemilik warisan.

Mengingat keistimewaan laki-laki yang didudukkan sebagai kepala keluarga menguatkan asumsi bahwa budaya patriarki mengkonstruksi laki-laki sebagai aktor sosial yang dominan mempraktikkan ketimpangan gender pada perempuan di masyarakat Pakpak (Bangun, 2009; Padang, 2009; dan Pardede 2010; Tinendung, 2011). Keberadaan laki-laki sebagai aktor patriarki dikaitkan denagan posisi mereka sebagai ayah, suami, saudara laki-laki dan juga kerabat laki-laki. Namun temuan dalam studi-studi tersebut tidak mengkaji keberadaan perempuan sebagai aktor patriarki yang berpotensi melakukan serta melanggengkan tindak ketimpangan gender pada perempuan.

Studi terhadap kasus-kasus marginalisasi perempuan di keluarga Pakpak memperlihatkan keberadaan perempuan sebagai aktor patriarkis seungguhnya berakar dari nilai-nilai patriarki yang diadopsi, dikonstruksi dan direproduksi oleh perempuan Pakpak yang berkedudukan sebagai ibu, mertua maupun ipar perempuan. Konstruksi ideologi gender yang berakar dari nilai-nilai patriarki menjadi landasan norma bagi sebagian besar perempuan Pakpak ketika mereka melaksanakan fungsi keibuan atau peribuannya 
(motherhood) di tengah keluarga bahkan di masyarakatnya.

Konstruksi ideologi gender patriarki yang direproduksi oleh perempuan diimplementasikan kedalam peran dan fungsi peribuan yang dimainkan oleh perempuan yang bersuami dan juga perempuan janda.Praktik marginalisasi pendidikan pada anak perempuan merupakan hal yang wajar dilakukan keluarga miskin terutama yang dikepalai oleh perempuan janda. Gambaran ini terlihat dari kasus-kasus anak perempuan yang tak bisa melanjutkan pendididikan ke sekolah menengah pertama (SMP) dan sekolah menengah atas (SMA) karena persoalan kemiskinan dan juga latarbelakang keluarga yang dikepalai perempuan janda. Bahkan kasus-kasus ini memperlihatkan bagaiamna nilai ganda diberlaklukan pada perempuan. Keaktoran dari perempuan selaku ibu (janda) yang menjadi pelaku utama marginalisasi perempuan dikontestasikan dalam kasus-kasus marginalisasi yang dialami perempuan yang berasal dari lapisan miskin. Perlakuan marginalisasi yang dialami perempuan dari lapisan ini cenderung menonjolkan bahwa aktor marginalisasi lebih dominan dimainkan oleh ibu (inang). Peran yang dimainkan oleh ibu dalam hal mengkonstruksi dan mereproduksi marginalisasi di keluarga ditunjukkan dalam berbagai tindakan dan keputusan yang cenderung opressif dan tendensius terhadap anak perempuannya.

Hal yang mendasari tindakan atau perlakuan opressif serta tendensius ibu (inang) meminta mereka berhenti sekolah seringkali didorong oleh alasan ekonomi atau kemiskinan. Ironisnya, di sisi lain para janda ini mempertahankan anak lakilakinya tetap sekolah. Realitas di keluarga miskin memperlihatkan pendidikan pada anak laki-laki lebih diprioritaskan ketimbang anak perempuan. Selain memprioritaskan sekolah untuk anak lakilaki, keluarga miskin cenderung mengarahkan anak perempuannya bekerja demi menopang ekonomi keluarganya. Pada keluarga miskin tampaknya diberlakukan "nilai ganda atau standar ganda" pada anak perempuan. Artinya, bagian yang menguntungkan seperti pendidikan dan harta warisan diberikan ke laki-laki dan sebaliknya pekerjaan dan tanggungjawab diserahkan pada perempuan.

Pertemuan ideologi gender patriarki dan kemiskinan mengakibatkan para ibu (janda) harus lebihmendahulukan kepentingan anak laki-lakinya daripada anak perempuan. Perlakuan ibu terhadap anak perempuannyadiungkapkan dalam kasus anak perempuan yang diputuskan oleh ibunya berhenti sekolah dan harus ikut kerabatnya di kota untuk memperoleh pekerjaan.

Perlakuan perempuan yang memarginalkan perempuan sebagaimana yang didekonstruksi dalam kasus-kasus marginalisasi perempuan dari keluarga miskin maupun kaya sangat dekat dan terlekat dengan sosok atau figurperempuan yang berkedudukan dan sekaligus memainkan peran sebagai ibu, mertua maupun ipar perempuan.Perempuan yang memiliki status sebagai ibu, mertua dan ipar perempuan mereproduksi nilai-nilai patriarki dalam peran keibuan (motherhood) mereka sehari-hari di tengah keluarganya.

Peran motherhood diterjemahkan dalam sejumlah perlakuan yang mengistimewakan anak laki-laki bagaikan seorang raja (make your son like king). Perlakuan ibu mengistimewakan anak lakilakinya diimplementasikan melalui sosialisasi dan internalisasi nilai patriarki pada anak perempuannya di keluarga. Pengistimewaan anak laki-laki dalam keluarga Pakpak dinyatakan dalam perintah dan arahan ibu pada anak perempuan untuk selalu menghormati, memuliakan dan melayani saudara laki-lakinya di keluarga. Semua perintah ibu biasanya mengatasa namakan laki-laki sebagai kula-kula (yaitu unsur tertinggi dalam struktur adat sulangsilima masyarakat Pakpak), penerus marga dan keluarga, pemimpin dan pembawa nama dan kehormatan keluarga. Konkritnya setiap ibu dan anak perempuan harus memberikan pelayanan yang terbaik mulai dari perhatian, makanan, pakaian dan pendidikan. Sebaliknya, harta warisan, kesempatan untuk maju dan prestisus diberikan pada laki-laki di keluarga.

\section{SIMPULAN}

Praktik-praktik marginalisasi perempuan dalam keluarga Pakpak di desa Pegagan Julu VIII telah mendekonstruksi ideologi gender perempuan sebagai aktor sosial yang berpotensi menguatkan dan melanggengkan struktur patriarki di masyarakat Pakpak. Ideologi gender perempuan yang patriarkis di keluarga menunjukkan keberadaan perempuan sebagai aktor patriarki dalam wilayah keluarga atau privat. Hal ini sejalan 
dengan dengan gagasan feminis Walby (1990) menyatakan bahwa patriarki yang dimainkan perempuan merupakan "patriarki privat". Inti dari teorinya tersebut telah terjadi ekspansi wujud patriarki, dari ruang-ruang pribadi dan privat seperti keluarga dan agama ke wilayah yang lebih luas yaitu negara. Ekspansi ini menyebabkan patriarki terus-menerus berhasil mencengkeram dan mendominasi kehidupan laki-laki dan perempuan.

Realitas marginalisasi perempuan dalam keluarga Pakpak sesungguhnya memperlihatkan suatu realitas ideologi gender perempuan yang mereproduksi sistem patriarki yang kemudian berproses menjadi norma dan nilai peribuan (motherhood) pada perempuan Pakpak. Realitas ini mendukung gagasan feminis feminis Einsthein, 1994 (dalam Ruwaida, 2004) yang menyatakan bahwa fenomena marginalisasi dan subordinasi ini tidak disebabkan oleh kondisi biologis perempuan, melainkan ini dibangun melalui struktur sosial, relasi sosial sekaligus kekuasaan antar kelompok dan atau antar aktor sosial. Oleh sebab itu menurut Eisentein, 1994 (dalam Ruwaida, 2004) bahwa kedudukan dan pengalaman perempuan menjadi sumber eksplorasi, termasuk keterlibatan perempuan dalam mensubordinasi atau menindas komunitas perempuan lainnya.

Ideologi gender patriarki pada perempuan Pakpak sekaligus meneguhkan suatu isu ketimpangan gender yang belum disoroti oleh studi-studi terdahulu yang konsen pada isu perempuan di masyarakat Pakpak. Demikian juga realitas ideologi gender perempuan yang patriarki belum menjadi sorotan pada agen pemerintah maupun lembaga swadaya masyarakat yang konsen menanggulangi isu-isu gender di wilayah perdesaan kabupaten Dairi secara umum dan masyarakat Pakpak desa Pegagan Julu VIII secara khusus. Patriarki yang tertanam dalam ideologi gender perempuan Pakpak di perdesaan telah memberi dampak berupa fenomena kemiskinan pada perempuan semakin sulit diatasi. Oleh karena itu studi ini menyarankan kepada pemerintah desa melalui biro pemberdayaan perempuan bersinergi dengan lembaga lain yang konsen pada isu-isu perempuan untuk melakukan penyadaran kesetaraan gender yang berkelanjutan terutama pada perempuan dan juga menyertakan laki-laki dalam rangka mengentaskan kesenjangan pendidikan dan juga kemiskinan pada kelompok perempuan.

\section{DAFTAR PUSTAKA}

Abdullah, I. (2001). Seks, Gender \& Reproduksi Kekuasaan. Yogyakarta: Tarawang.

Alpizar, L, (2003), Impunity and Women's Right in Ciudad Juarez, Carnegie Council on Ethics and International Affairs. http: //www.carnegie council. org/view media.php/prml D/1056S.

Cevallos, D. (2003). Mexixo: Toll of Murdered Young Women Tops 300http.//www. corpwatch.org.

Cravey, A.J.(1998), Women and Work in Mexico's Maquila doras, Maryland: Rowman and Litlefield. Publishers Inc.

Erturk, Y. (2007). "Intersection Betwen Culture and Violence against Women http://daccess.ods.un.org/TMP/367090225219727.html.

Fakih, M. (1996), Analisis Gender dan Transformasi Sosial, Yogyakarta Penerbit: Pustaka Pelajar.

Irianto, S, (2003), Perempuan Di Antara Berbagai Pilihan Hukum: Studi Mengenai Strategi Perempuan Batak untuk Mendapatkan Akses" kepada Harta Waris melalui Proses Penyelesaian Sengketa. Jakarta: Fisip-UI dengan Penerbit Obor.

Moser, CON. (1993), Gender Planning and Development, Theory, Practice and Planning, London,: Routledges.

Pantaleo, K, (2006),

Gendered Violence, Murder in the Maquiladoras, Pennysylvania, California University.

Pardede, E. (2010), Menelusuri Bentuk-bentuk Kekerasan Perempuan di MasyarakatAdat, Sidikalang: Penerbit Pesada.

Ramazanoglu, C. and Holland, J. (2002). Feminist Methodology (Challenges and Choices). London: Sage Publications.

Simanjuntak, A.B. (2006). Struktur Sosial dan Sistem Politik Batak Toba (Suatu Pendekatan Sejarah, Antropologi Budaya Politik), Jakarta: Yayasan Obor Indonesia.

Shirkat, G. (2001), Karo Kari, Tor Tora, Siyahkari Kala Kali (There is no honour" in killing). Lahore: ShirkatGah: Women"s Resource Centre.

Walby, S. (1990), Theorizing Patriarchy, Oxford, Basic Blackwell Ltd

Wijaya, H.R. (1996), Penelitian Berpersfektif Gender", Jurnal Analisis Sosial Edisi 4/Nopember 1966, Bandung, Akatiga.

Tinendung, S. (2012). Analisis Posisi Perempuan dalam Status Sosial Keluarga Pakpak. Skripsi: Sosiologi. Fakultas Ilmu Sosial Politik, Universitas Sumatera Utara. 
Venny, A. (2006). "Pentingnya Metodologi Feminis di Indonesia", Jakarta, Jurnal Perempuan Nomor 48.

Oakley, A. (1972). Sex, Gender and Society. London, Temple Smith.

Agarwal, A, (2009), Crimes of Honor: An International Human Rights Perspective onViolence Against Women in Southasia, Dissertation University of South California.

Bangun, S. (2009). Ketertinggalan Perempuan Batak Pakpak dalam Memperoleh Pendidikan Formal, http//isjd.pdii.lipi.go.id/index.php/Search.html?a ct $=$ tampil\&id $=74113 \& i d c=45$

Boangmanalu, A.S. (2009), Pandangan PKS Pakpak Barat terhadap Partisipasi Politik Perempuan, Tesis, Magister Studi Pembangunan, Fakultas Ilmu Sosial dan Politik, USU.

Ihromi, T.O.. (1986). Masyarakat dan Hukum Adat Toba, Jakarta: Pustaka Aset

Martinez, S.F. (2008), Gender, The State and Patriarchy: Partner Violence in Mexico, Austin, Dissertation, Austin, University of Texas.

Naeem, N.R. (2011), Exploratory Study of Countries Lackin g Data on Female Genital Mutilation in The Middle East and Africa, Thesis: Sociology Old Dominion University and Norfolk State University.

Padang, A.P.

(2009), Kedudukan Perempuan Etnik Pakpak dalam Memperoleh Pendidikan Formal, Skripsi Antropologi, Fakultas Ilmu Sosial Politik , Universitas Sumatera Utara.

Panther, N, (2007), Violence against Women and Feminicide in Mexico: The Case of Ciudad Juarez, Thesis, The Oklahoma State University. Paiz, Godoy Paula L. 2011,Looking Back, Seeing Forward: An Ethnography Of Women And Violence In Post-War

Ruwaida, I. (2010). Pemberdayaan Ekonomi Perempuan: Kajian Dinamika Lokal Dalam Perspektif Gender (Analisis Komparatif Kabupaten Lombok Timur Dan Kabupaten Bima, Nusa Tenggara Barat). Disertasi: Sosiologi. Universitas Indonesia.

Simbolon, I.J. (1998). Peasant Women and Access to LandCostomary law, State Law and Gender Based Ideology, The Case of the Batak Toba (North Sumatera). Ponsen \& Looijen b. V.Wageningen.

Tinendung, S. (2012), Analisis Posisi Perempuan dalam Status Sosial Keluarga Pakpak, Skripsi:
Sosiologi, Fakultas Ilmu Sosial Politik,Universitas Sumatera Utara.

Tridewiyanti, K, (2009). Perempuan Arab Ba-alawi dalam Sistem Perkawinan: Reproduksi Kebudayaan dan Resistensi, Disertasi, Antropologi, Universitas Indonesia.

Abell, H. (1999), "Endangring Women's Health for Profit: Health and Safety in Mexico's Maquiladoras", Development in Practice 9:595:600, Oxfam GB, Routledge.

Chester, B. Robin, R.W. \& Koss, M. P. (1994), "Grandmother Dishonored: Violence Against by Male Partners in American Indian Communities", Native North American, Volume. 9. No.3, Springer Publishing Company.

Hunter, A. (2005), "The Violence that Indigenous Women Face"; Native North American Canada in Journal Political Science, Vol.39. No.2, Winnipeg Canada: Canadian Dimension.

Maria, M. (2003), "The Violence Continues Against the Participation of Women and

Their Organication", Women\& Environments International Magazine, Vol/Issue $\quad 58 / 59$ .Toronto, WEED Foundation.

McFadden, M. (2001), “On Unprotected Females, Violence, and Survival in the New World: Introduction", Women's Interests, Vol.13. No.1, Baltimore, Johns Hopkins University Press.

Menjívar, C. (2008), “Violence and Women's Lives in Eastern Guatemala: A Conceptual

Framework" , Social Sciences: Comprehensive Works, Education, Political Science-International Relations, Vol.3/Issue1,Pittsburgh, Latin American Studies Association

Munthe, H.M. (2007), "Modernisasi dan Perubahan Sosial Masyarakat dalam Pembangunan Pertanian: suatu Tinjauan Sosiologis", Jurnal Harmoni Sosial, Volume II, No. 1

Munthe, H.M. (2017), Phenomenon of Women Marginalization in Poor Family in Pakpak Community: "A Case Studi in PegaganJulu Village, Sumbul Subdistrict, Dairi Regency, North Sumatera", Journal of Arts \& Humanities, Volume 06 , Issues $06,38-51$. 